\title{
The Impact of Tobacco Control Policies on Smoking Among Socioeconomic Groups in Nine European Countries, 1990-2007
}

\section{$\mathrm{Hu}$, Yannan}

2017-12

Hu , Y, van Lenthe , F J , Platt , S, Master , J R B , Lahelma , E, Menvielle , G, Regidor , E , Santana , P , de Gelder , R \& Mackenbach , J P 2017 , ' The Impact of Tobacco Control Policies on Smoking Among Socioeconomic Groups in Nine European Countries, 1990-2007

' , Nicotine \& Tobacco Research , vol. 19 , no. 12 , pp. 1441-1449 . https://doi.org/10.1093/ntr/ntw210

http://hdl.handle.net/10138/312126

https://doi.org/10.1093/ntr/ntw210

acceptedVersion

Downloaded from Helda, University of Helsinki institutional repository.

This is an electronic reprint of the original article.

This reprint may differ from the original in pagination and typographic detail.

Please cite the original version. 
The impact of tobacco control policies on smoking among socioeconomic groups in nine European countries, 1990-2007

Yannan Hu, Frank J. van Lenthe, Ken Judge, Steve Platt, Anton Kunst, Jizzo R. Bosdriesz, Giuseppe Costa, Johannes Klotz, Eero Lahelma, Richard Layte, Gwenn Menvielle, Enrique Regidor, Paula Santana, Rianne de Gelder, Johan P. Mackenbach

*Correspondence author:

Prof. Dr. Johan P. Mackenbach

Department of Public Health

Erasmus MC

P.O. Box 2040

3000 CA Rotterdam 


\section{ABSTRACT}

\section{Background}

Whether tobacco control policies have contributed to a narrowing or widening of socioeconomic inequalities in smoking in European countries in the past two decades is uncertain. This paper aims to investigate the impact of price and non-price related tobacco control efforts on smoking by socioeconomic group in 9 European countries between 1990 and 2007.

\section{Methods}

Education, occupation and smoking status were obtained from nationally representative surveys. Tobacco control policies in countries were measured by the relative affordability ("price") of cigarettes and a summary score of four domains of non-price policies. The associations between tobacco control policies and smoking were studied using country fixed effects models, stratified by education and occupation.

Results

In the total population, higher cigarette prices were significantly associated with a lower prevalence of smoking among women, and more non-price tobacco control efforts were significantly associated with a lower prevalence of smoking among men. While these favourable effects were generally in the same direction for all socioeconomic groups, they were larger and statistically significant in the lower socioeconomic groups only.

\section{Conclusions}

Tobacco control policies as implemented in European countries have probably helped to reduce the prevalence of smoking in the total population, particularly in lower socioeconomic groups. The widening inequalities in smoking must be explained by other factors, and suggests that policies with larger effects on lower socioeconomic groups are needed to reverse this trend. 


\section{INTRODUCTION}

Socioeconomic inequalities in smoking widened in many European countries in the 80's and 90's of the previous century, mainly because the decline in the prevalence of smoking was larger among those in higher as compared to lower socioeconomic groups. ${ }^{1}$ Recent evidence suggests that higher educated more often quitted smoking in the first decade of the new century as well, although trends in smoking cessation varied between countries. ${ }^{2}$

Widening inequalities in smoking seem at odds with intensified tobacco control policies in many European countries. ${ }^{3}$ For example, comprehensive tobacco control policies were implemented in the United Kingdom, containing a ban on tobacco advertising on television in 1990, health warnings on cigarette packages since 1991, and the expansion of the tobacco cessation services since $1992 .{ }^{4}$ Similar developments in tobacco control policies were found in many other countries. ${ }^{4}$ An important question is whether tobacco control policies adopted in European countries affected socioeconomic groups equally.

The most consistent evidence from systematic reviews is that higher prices for cigarettes had a disproportionately greater impact on the most disadvantaged smokers and as such contributed to a reduction in inequalities in smoking. ${ }^{56}$ The equity impact of many other tobacco control policies are less consistent, and those including mainly voluntary, regional and partial smoke free policies might have even increased inequalities in smoking. ${ }^{6}$ Further, previous studies evaluating the impact of populationlevel tobacco control policies on socioeconomic inequalities in smoking are mainly restricted to a single country (e.g. the United States or the United Kingdom) $)^{7-10}$ or a small number of countries at best. ${ }^{11-14}$ Differences in the societal context in which these policies were implemented, however, may hamper the external validity of the effects. One notable exception is a cross-sectional study of 18 European countries in which a comprehensive package of tobacco control policies, as measured by the tobacco control scale $(\mathrm{TCS})^{15}$, was related to higher quit ratios, without significant differences between

educational groups. ${ }^{16}$ As the TCS score is only available for a limited number of recent years, ${ }^{15}{ }^{17-20}$ it can only be used for evaluations over a relatively short period of time.

For important price and non-price related elements of a comprehensive tobacco control policy, data are available for a longer period of time. Blecher et al. developed an indicator of the affordability of cigarettes, defined as the percentage of per capita GDP required to purchase the 100 cheapest packs of cigarettes. $^{2122}$ Currie developed a non-price related policy indicator (the Tobacco Control Policy Index), which included four domains of the TCS: smoking bans or restrictions in public places and workplaces, comprehensive bans on advertising and promoting, health warning labels and cessation services. ${ }^{4}$ This paper aims to investigate the impact of both price and non-price related tobacco control efforts on smoking by socioeconomic group in 9 European countries between 1990 and 2007.

\section{DATA AND METHODS}

Data 
We used data made available by Blecher and Currie to represent key aspects of the tobacco control policy development (TCPD). ${ }^{421}$ In order to measure the cigarette affordability, Blecher estimated the relative income price of cigarettes (the percentage of per capita GDP required to purchase the 100 cheapest packs) for a large number of countries for the period of 1990-2008, using the cigarette price data from the Economist Intelligence Unit. ${ }^{21} 22$ Currie developed a Tobacco Control Policy Index, which estimated scores for four non-price domains of the TCS (smoking bans or restrictions, comprehensive bans on advertising and promoting, health warning labels and cessation services) for 11 European countries from 1950-2010. ${ }^{4}$ The index is based on the same weights as applied in the TCS ${ }^{15}$ to yield a maximum score for the four domains of 55 , which is then rebased to a maximum score of 100 . Both the data on the cigarette affordability and the non-price Tobacco Control policy Index were measured annually.

Data on individual-level smoking status, age, sex and socioeconomic position were obtained from nationally representative health surveys for 9 European countries (Finland, Ireland, the United Kingdom, Austria, the Netherlands, France, Italy, Portugal and Spain) for a number of years between 1990 and 2007 (Table 1). The selected surveys were either identical (for most of the countries) or had a high degree of comparability within country over time (for Austria, the Netherlands and Italy). ${ }^{23-26}$ We constructed our final dataset by matching the individual-level survey data to the country-level data on cigarette affordability developed by Blecher (further referred to as "price") and the summary scores for four non-price policy domains developed by Currie (further referred to as "non-price"). For some countries and years, price and non-price measures were excluded from the analysis, if the national health survey data of the corresponding countries or years were not available. The final dataset included observations of 563,987 individuals from 9 countries with 33 country-year observations between 1990 and 2007. The age range used for most countries in the analysis was 30-79 years. Younger respondents were excluded because many of them were still receiving full-time education. Older respondents were excluded to avoid the potential bias caused by the exclusion of the institutionalized population in most surveys. The upper age limits in some countries are lower than 79 years (France (30-74), Ireland (30-74) and the United Kingdom (30-69)).

Smoking status was measured as whether the respondent was a current smoker (both daily or occasional smoker in all countries, except for Austria where only daily smoker was included). Socioeconomic position was measured by educational level and occupational class. Educational levels were recorded as the highest level of education completed or currently attended by a person. It was harmonized on the basis of the International Standard Classification of Education (ISCED) and reclassified into 3 categories: levels 0-2 (no, primary or lower secondary education, considered "low education"), levels 3-4 (upper secondary and post-secondary non-tertiary education, considered "middle education"), levels 5-6 (tertiary education, considered "high education"). Occupational classes were classified as "manual" versus "non-manual". Respondents who were economically inactive, and who could not be classified on the basis of their last or main occupation, were classified as missing.

Gross Domestic Product (GDP) per capita was used as a confounding variable, as it may be related to both smoking behaviour and the implementation of tobacco control policies. ${ }^{16}$ Moreover, it may also be 
used as a proxy measure of the stages in the spread of the smoking epidemic. ${ }^{27}$ GDP per capita (constant prices, constant purchasing power parity rates) was extracted from OECD Stat (http://stats.oecd.org/).

Statistical methods

Logistic regression models were used to analyze the associations between the country-level tobacco control policy measures and the individual-level smoking status. We applied fixed effects analysis by adding the country dummy variables into the models. This allowed us to adjust for unobserved timeinvariant country heterogeneities related to both the implementation of tobacco control efforts and smoking in countries. Additionally, we adjusted the analysis for age, age squared, logarithmic form of GDP and period dummy variables. Clustered sandwich estimators were used to allow for within-country correlation between error terms. ${ }^{28}$

The basic model can be written as:

smoking $_{i j t}=\beta_{0}+\beta_{1} \ln (\text { price })_{j t}+\beta_{2}(\text { non }- \text { price })_{j t}+\beta_{3} a g e_{i j t}+\beta_{4} a g e_{i j t}^{2}+\beta_{5} \operatorname{lng} g p_{j t}+T_{t}+X_{j}$

where smoking $_{i j t}$ is a dummy variable indicating whether the respondent $\mathrm{i}$ in country $\mathrm{j}$ was a current smoker in year $\mathrm{t} ; \beta_{0}$ is a constant; $\ln (\text { price })_{j t}$ represents the logarithmic form of the relative income price of cigarettes developed by Blecher for country $\mathrm{j}$ in year $\mathrm{t}$, accounting for the potential non-linear relationship between price and smoking; (non-price) ${ }_{j t}$ is the non-price related policy measure for country $\mathrm{j}$ in year $\mathrm{t}$; $a g e_{i j t}$ and $a g e_{i j t}^{2}$ are the age and age squared of the respondent; $\operatorname{lng} d_{j t}$ is the logarithmic form of GDP per capita; $T_{t}$ is a vector of the 5 -year period dummies controlling the shared time trend in smoking; $X_{j}$ is a vector of country dummies, controlling the time-invariant country heterogeneities in propensity towards smoking or making tobacco control efforts, which are affected by the long-term country-specific cultural or political factors, e.g. the religion composition of population ${ }^{29}$ or the power of the tobacco industry ${ }^{3031}$. Additionally, by adding country dummies we controlled for the potential national differences in reporting or recording smoking behaviours.

The basic model was conducted separately for men and women. Given that our primary interest was to assess whether tobacco control policies affected socioeconomic groups equally, we further stratified the analysis by education and occupation. To empirically test whether the associations between the policy measures and smoking differed significantly between educational or occupational groups, interactions between the policy measures and education or occupation were added, together with the corresponding interactions between the other variables in the basic model and education or occupation.

In the Web appendix, supplementary analyses include an a) analysis incorporating weighting factors that were available in the surveys of some countries or years (Table A1); b) analysis using the amount of smoking per day among current smokers as the outcome in linear regression models (Table A2); c) analysis allowing potential lagged effects of the non-price policies (Table A3); d) analysis replacing the price indicator by an index which measures the price of a pack of cigarettes in the most popular price category divided by GDP per capita expressed in purchasing power standards ${ }^{32} 33$ (Table A4); e) analysis 
using a constructed measure combining the price and non-price measures (Table A5); f) analysis linking each of the four domains of the non-price score to smoking (Table A6);.

All regression analyses were performed in Stata 13.1.

\section{RESULTS}

Summary statistics of key variables are presented in Table 2. The education distribution differs between countries, with the highest percentage of high-educated group found in Ireland, followed by France and the United Kingdom, and the highest proportion of non-manual workers in France, followed by Finland and the Netherlands. The smoking prevalence ranged from 20\% (Portugal) to 33\% (the Netherlands). The mean of GDP was higher in Ireland and the Netherlands, and was generally lower in the Mediterranean countries. Averaged over time, the relative income price of cigarettes was highest in the United Kingdom, followed by Portugal and Ireland, and was lowest in Spain. Averaged over time, the non-price policy indicator was highest in Ireland and lowest in Austria.

Figure 1 shows the trends in the price and non-price measures by country over the study period. A relatively stable trend in the price indicator was observed in most of the countries, except for an increasing trend in France and the United Kingdom, and a decreasing trend in Ireland. The non-price indicator constantly increased over time in all available countries.

Figure 2.a and figure 2.b show the trends in age-standardized smoking prevalence by education in each country for men and women separately. ${ }^{34}$ Among men, smoking was more prevalent in low-educated group in almost all countries and years. The smoking prevalence generally decreased to the same extent over the study period within each educational group. Among women, smoking was more prevalent among lower-educated group in many countries. While the smoking prevalence among the loweducated was generally stable, it often declined among the high-educated group. Deviant trends were found in Italy, Portugal and Spain. In these countries, the smoking prevalence was higher among higheducated in the 1990s, but was almost equal to the prevalence among the low-educated in 2005. Essentially similar trends were observed in age-standardized smoking prevalence by occupation (appendix, figure A1).

Table 3 shows the results from logistic regressions linking the tobacco control policy measures to smoking. In the total population, an increase in the non-price related tobacco control policies was significantly associated with a lower probability of smoking among men $\left(\mathrm{OR}=0.995,95 \% \mathrm{Cl}\left(0.991^{\sim}\right.\right.$ $0.999))$. An increase in the relative income price was significantly associated with a lower probability of smoking among women $\left(\mathrm{OR}=0.502,95 \% \mathrm{Cl}\left(0.337^{\sim} 0.749\right)\right)$. Stratified by education or occupation, most odds ratios were still below 1 and significant associations were found in low socioeconomic groups only. Specifically, the non-price related policy measure was negatively related to smoking among men with low education ( $\mathrm{OR}=0.995,95 \% \mathrm{Cl}(0.992 \sim 0.999)$ ), and the price related policy measure was negatively associated with smoking among women with low education (OR=0.545, 95\% Cl (0.365 0.815)) or 
manual jobs $(\mathrm{OR}=0.489,95 \% \mathrm{Cl}(0.350 \sim 0.683))$. While the odds ratios were always smaller in the low socioeconomic groups, they were not statistically different from those in the high socioeconomic groups, as indicated by the $p$-value of the interactions.

Essentially similar results were obtained in a sensitivity analysis (appendix, table A1), in which weighting factors were incorporated if available. Using the daily amount of smoking as the outcome, significant associations between tobacco control policy measures and smoking were mainly found again in the lower socioeconomic groups (table A2). Analyses in which the 1-year and 2-year lagged effects of the non-price policy measure were additionally added in the models, showed that significant results were mainly found with the contemporaneous non-price policy measure (table A3). Consistent with the main findings, none of the interactions between the contemporaneous or lagged non-price measures and the socioeconomic position was significant.

\section{DISCUSSION}

Summary of findings

In the total population, higher cigarette prices were significantly associated with a lower prevalence of smoking among women, and more non-price tobacco control efforts were significantly associated with a lower prevalence of smoking among men. While these favourable effects were generally in the same direction for all socioeconomic groups, they were larger and statistically significant in the lower socioeconomic groups only.

Strengths and limitations

By covering 9 European countries, multiple elements of tobacco control efforts and a period of nearly 20 years, we comprehensively investigated the impact of tobacco control efforts adopted in European countries on smoking by socioeconomic group. Two indicators (education and occupation) were used to capture the multidimensional nature of the concept of socio-economic position and to ensure the robustness of the findings. Country fixed effects models were used to reduce the potential bias caused by unobserved country factors related to both the implementation of tobacco control efforts and the prevalence of smoking in countries. As such, these models improved the causal inference of the relationships reported.

However, although we were able to control for such unobserved time-invariant confounding, the results may be still biased due to the omitted time-variant confounders. ${ }^{28}$ For example, increasing knowledge about the health consequences of smoking may have been related to the implementation of tobacco control policies, as well as to changes in the smoking prevalence. Further studies may consider to include the potentially omitted time-variant confounders, if appropriate data are available.

The indicator of cigarette affordability measures the relative income price of the 100 cheapest packs of cigarettes. While the cheapest packs may be most relevant for those in lower socioeconomic groups, 
they may not be the packs most often bought. We therefore replicated the analysis using a cigarette price index which measured the price of a pack of cigarettes in the most popular price category divided by GDP per capita expressed in purchasing power standards (Table A4). ${ }^{32} 33$ Opposite to the results using Blecher's affordability indicator, the results suggested that men were more responsive to this price indicator than women. However, with regard to the impact on smoking by socioeconomic group, the results resembled those seen for Blecher's affordability indicator; the potential favourable effects were statistically significant in the lower socioeconomic groups only and no statistically significant differences were found between socioeconomic groups. It suggests that our main findings are robust against the usage of another cigarette price measure.

By using the non-price Tobacco Control Policy Index, we tried to cover the most important domains of non-price related policies. The index excluded the domain of public (mass media) information campaigns, which were present in some countries. For example, in the Netherlands a large campaign ("The Netherlands starts quitting/The Netherlands continues with quitting") was implemented in 2003$2004,{ }^{35}$ and in England a free telephone help line advertised by TV and radio was introduced since 1994. ${ }^{36}$ There is however, no consistent evidence on the equity impact of mass media campaigns, ${ }^{6}$ and existing European studies sometimes even suggest a widening of inequalities. ${ }^{36-38}$ Therefore, it is unlikely that we have missed major favourable effects of tobacco control efforts on inequalities in smoking due to the exclusion of the mass media campaigns.

We included measures for price and non-price tobacco control efforts simultaneously in the analysis. Mutual adjustment enabled us to distinguish their potential different impacts on smoking inequalities. ${ }^{6}$ At the same time, however, this approach does not directly provide insight in the equity impact of a comprehensive tobacco control implemented as a whole in European countries. Therefore, we also constructed a summary measure which was a sum of the price and non-price indicators using the same weights as the TCS. ${ }^{15}$ The results using this summary measure showed that more tobacco control efforts in the European countries included were significantly related to lower smoking prevalence among men and in lower socioeconomic groups among women (Table A5). Again, the favourable results were statistically significant in lower socioeconomic groups only.

Interpretations

Our results suggest that both price and non-price population-wide tobacco control efforts in European countries have helped to reduce smoking among the total population and among people in low socioeconomic groups. This is consistent with some previous findings. ${ }^{5639}$

An intriguing finding from our study is the gender difference in the impact of price and non-price related efforts. Women appeared to be more responsive to the change in the price of the cheapest cigarettes than men. One potential explanation is that women generally have less income than men, ${ }^{40}$ which might make women more responsive to the change of cigarette price, especially the price of the cheapest cigarette. In a sensitivity analysis (Table A4), we found men to be more responsive to the price of cigarettes in the most popular category, which was not necessarily the price of the cheapest cigarette. 
This partly supports our explanation and suggests that the specific choice of the price measure could be a potential reason for the discrepancies in the existing studies about the gender difference in the price elasticity.

The majority of existing studies suggest that increasing the price of tobacco products may be more effective in reducing smoking among lower socioeconomic groups, although there is also some evidence to suggest neutral or negative equity impact of the cigarette price. ${ }^{56}$ In our study, no matter which price measure we used, the significantly negative associations between price and smoking were only found among the lower socioeconomic groups in the stratified analysis, suggesting that people in lower socioeconomic groups might be more responsive to the change of price. People in higher socioeconomic groups may not regard the cost of cigarettes as a heavy financial burden, which would make them less sensitive to the change of cigarette price. ${ }^{41}$ However, there are also some other countervailing factors which might weaken the potential equity impact of the cigarette price. For example, people in lower socioeconomic groups are more frequently heavier smokers and tobacco-dependent, and may turn to hand-rolled cigarettes when the cigarette price increases. ${ }^{42} 43$ Moreover, smokers in lower socioeconomic groups may satisfy more essential needs with smoking (e.g. the reduction of negative feelings, cheap leisure), and harsh living conditions may make quitting smoking harder. ${ }^{42}$ All these factors together could make the differences in the reactions to the cigarette price between socioeconomic groups much smaller than we expected. As our study suggests, while the impact was larger and statistically significant among lower socioeconomic groups only, differences in the associations between price and smoking were not statistically significant between socioeconomic groups.

In the supplementary analysis linking the four domains of the non-price policy measure to smoking, none of the sub-domains of the non-price policies consistently showed a differential impact by socioeconomic position on smoking (Table A6). This corresponds to previous review studies, which found the equity impact of the non-price tobacco control efforts were uncertain. ${ }^{5}$ To interpret the findings, we have also to be aware that the policy indicators like the Tobacco Control Policy Index measure the extent to which tobacco control policies have been formulated, but contain little information on their enforcement in practice. ${ }^{44} \mathrm{~A}$ possible issue is that the efforts were not well implemented and faced considerable problems with compliance in some European countries. ${ }^{345}$ If we are able to account the real enforcement of the policies, the estimated equity impact of the non-price policies on smoking might be larger.

The effects of tobacco control policies were found to be larger and statistically significant among the lower socioeconomic groups only, which suggests that these policies may have contributed to a reduction of inequalities in smoking. We tried to quantify the impact of the policies on inequalities in smoking, using the average age-standardized prevalence by educational level in all countries in the first available year of our study and the change in prevalence of smoking in higher and lower socioeconomic groups over a ten-year period as predicted by the average yearly change in the policy indexes (analyses not shown, available upon request). We found that, keeping all other variables constant, educational inequalities would attenuate slightly among men (a reduction of the relative inequalities by $12 \%$, and a 
reduction of absolute inequalities by $16 \%$ ), and more substantially among women (in countries where smoking was more prevalent among low-educated women than high-educated women at the beginning, relative inequalities would be reduced by $42 \%$ and absolute inequalities would be reduced $43 \%$ ). This suggests that tobacco control policies as implemented in European countries have not contributed to a widening of inequalities in smoking, but may instead have contributed to a certain degree of narrowing. Other factors must have been responsible for this widening trend in smoking inequalities, such as differences across socioeconomic groups in knowledge of the risks of smoking, ${ }^{46} 47$ and the economic recessions in some European countries during the study period (e.g. Finland in the early 1990s). ${ }^{48} 49$

\section{Conclusions}

Tobacco control policies as implemented in European countries have probably helped to reduce the prevalence of smoking in the total population, particularly in lower socioeconomic groups. The widening inequalities in smoking must be explained by other factors, and suggests that policies with larger effects on lower socioeconomic groups are needed to reverse this trend. 


\section{REFERENCE}

1. Giskes K, Kunst AE, Benach J, Borrell C, Costa G, Dahl E, et al. Trends in smoking behaviour between 1985 and 2000 in nine European countries by education. J Epidemiol Community Health 2005;59(5):395-401.

2. Bosdriesz JR, Willemsen MC, Stronks K, Kunst AE. Socioeconomic inequalities in smoking cessation in 11 European countries from 1987 to 2012. J Epidemiol Community Health 2015;69(9):886-92.

3. Currie L, Gilmore AB. Tobacco. In: Mackenbach JP, Mckee M, editors. Successes and Failures of Health Policy in Europe: four decades of divergent trends and converging challenges. Buckingham: Open University Press, 2013.

4. Nguyen L, Rosenqvist G, Pekurinen M. Demand for Tobacco in Europe: An Econometric Analysis of 11 Countries for the PPACTE Project. Tampere, Finland: Juvenes Print, 2012.

5. Thomas S, Fayter D, Misso K, Ogilvie D, Petticrew M, Sowden A, et al. Population tobacco control interventions and their effects on social inequalities in smoking: systematic review. Tob Control 2008;17(4):230-7.

6. Brown T, Platt $S$, Amos A. Equity impact of population-level interventions and policies to reduce smoking in adults: a systematic review. Drug Alcohol Depend 2014;138:7-16.

7. Colman GJ, Remler DK. Vertical equity consequences of very high cigarette tax increases: If the poor are the ones smoking, how could cigarette tax increases be progressive? J Policy Anal Manag 2008;27(2):376-400.

8. Dinno A, Glantz S. Tobacco control policies are egalitarian: A vulnerabilities perspective on clean indoor air laws, cigarette prices, and tobacco use disparities. Soc Sci Med 2009;68(8):1439-47.

9. Hawkins SS, Cole TJ, Law C. Examining smoking behaviours among parents from the UK Millennium Cohort Study after the smoke-free legislation in Scotland. Tobacco Control 2011;20(2):112-18.

10. Taggar JS, Coleman T, Lewis S, Szatkowski L. The impact of the Quality and Outcomes Framework (QOF) on the recording of smoking targets in primary care medical records: cross-sectional analyses from The Health Improvement Network (THIN) database. BMC Public Health 2012;12.

11. Nagelhout GE, Mons U, Allwright S, Guignard R, Beck F, Fong GT, et al. Prevalence and predictors of smoking in "smoke-free" bars. Findings from the International Tobacco Control (ITC) Europe Surveys. Soc Sci Med 2011;72(10):1643-51.

12. Hitchman SC, Mons U, Nagelhout GE, Guignard R, McNeill A, Willemsen MC, et al. Effectiveness of the European Union text-only cigarette health warnings: findings from four countries. Eur J Public Health 2012;22(5):693-9.

13. Kasza KA, Hyland AJ, Brown A, Siahpush M, Yong HH, McNeill AD, et al. The effectiveness of tobacco marketing regulations on reducing smokers' exposure to advertising and promotion: findings from the International Tobacco Control (ITC) Four Country Survey. Int J Environ Res Public Health 2011;8(2):321-40.

14. King BA, Hyland AJ, Borland R, McNeill A, Cummings KM. Socioeconomic variation in the prevalence, introduction, retention, and removal of smoke-free policies among smokers: findings from the International Tobacco Control (ITC) Four Country Survey. Int J Environ Res Public Health 2011;8(2):411-34.

15. Joossens L, Raw M. The Tobacco Control Scale: a new scale to measure country activity. Tob Control 2006;15(3):247-53.

16. Schaap MM, Kunst AE, Leinsalu M, Regidor E, Ekholm O, Dzurova D, et al. Effect of nationwide tobacco control policies on smoking cessation in high and low educated groups in 18 European countries. Tob Control 2008;17(4):248-55. 
17. Joossens L. Effective Tobacco Control Policies in 28 European Countries. Available online at: http://old.ensp.org/files/effectivefinal2.pdf (accessed 12 Nov 2015), 2004.

18. Joossens L, Raw M. Progress in Tobacco Control in 30 European Countries, 2005 to 2007. Available online

at:: http://www.europeancancerleagues.org/images/stories/pdf/290 30 european countries text final.pdf (accessed 12 Nov 2015), 2007.

19. Joossens L, Raw M. The Tobacco Control Scale 2010 in Europe. Available online at: https://www.krebshilfe.de/fileadmin/Inhalte/Downloads/PDFs/Kampagnen/TCS 2010 Europe. pdf (accessed 12 Nov 2015): Association of European Cancer leagues, 2011.

20. Joossens L, Raw M. The Tobacco Control Scale 2013 in Europe. Available online at: http://www.europeancancerleagues.org/images/TobaccoControl/TCS 2013 in Europe 13-0314 final 1.pdf (accessed 12 Nov 2015): Association of European Cancer leagues, 2014.

21. Blecher EH. The Economics of Tobacco Control in Low- and Middle-income Countries. Thesis presented for the degree of Doctor or Philosophy, School of Economics, University of Cape Town. Available online at: http://uctscholar.uct.ac.za/PDF/32601 Blecher,\%20E.pdf (accessed 12 Nov 2015), 2011.

22. Blecher EH, van Walbeek CP. Cigarette affordability trends: an update and some methodological comments. Tob Control 2009;18(3):167-75.

23. Großschadl F, Stronegger WJ. Long-term trends in obesity among Austrian adults and its relation with the social gradient: 1973-2007. European Journal of Public Health 2013;23(2):306-12.

24. European Foundation for the Improvement of Living and Working Conditions. Trends in quality of work in the Netherlands. http://eurofound.europa.eu/sites/default/files/ef files/ewco/surveys/NL0601SR01/NL0601SR0 1.pdf (accessed 11 December 2014), 2007.

25. Italian National Institute of Statistics (ISTAT). Condizioni di salute e ricorso ai servizi sanitari [Health and Health Care Utilization]. Italian National Institute of Statistics, http://www.istat.it/it/archivio/5471 (accessed 12 December 2014).

26. Italian National Institute of Statistics (ISTAT). Multipurpose Family Survey. Italian National Institute of Statistics, http://www.istat.it/it/archivio/4394 (accessed 16 July 2015).

27. Schaap M. Socioeconomic inequalities in smoking in Europe. PhD dissertation. Erasmus University Rotterdam., 2010.

28. Wooldridge JM. Econometric analysis of cross section and panel data (second edition): MIT Press, 2010.

29. Garrusi B, Nakhaee N. Religion and Smoking: A Review of Recent Literature. Int J Psychiat Med 2012;43(3):279-92.

30. McKee M, Diethelm P. How the growth of denialism undermines public health. BMJ 2010;341:c6950.

31. Gilmore $A B$, Tavakoly $B$, Taylor $G$, Reed $H$. Understanding tobacco industry pricing strategy and whether it undermines tobacco tax policy: the example of the UK cigarette market. Addiction 2013;108(7):1317-26.

32. Bosdriesz JR, Nagelhout GE, Stronks K, Willemsen MC, Kunst AE. The Association Between Tobacco Control Policy and Educational Inequalities in Smoking Cessation in the Netherlands from 1988 Through 2011. Nicotine Tob Res 2015;17(11):1369-76.

33. Bosdriesz JR, Willemsen MC, Stronks K, Kunst AE. Patterns of Tobacco Control Policy Progress in 27 European Countries. Tobacco Regulatory Science 2015;1(3):254-64.

34. Ahmad OB, Boschi-Pinto C, Lopez AD, Murray CJL, Lonzano R, Inoue M. Age Standardization of Rates: a New WHO Standard. . GBP Discussion Paper Series No. 31. World Health Organization http://www.who.int/healthinfo/paper31.pdf (accessed 10 October 2014) 2001. 
35. van den Putte B, Yzer MC, ten Berg BM, Steevels RMA. Nederlands Start Met Stoppen/Nederlands Gaat Door Met Stoppen. Evaluatie van de STIVORO campagnes rondom de jaarwisseling 20032004. Amsterdam: Universiteit van Amsterdam, 2005.

36. Owen L. Impact of a telephone helpline for smokers who called during a mass media campaign. Tob Control 2000;9(2):148-54.

37. van Osch L, Lechner L, Reubsaet A, Steenstra M, Wigger S, de Vries H. Optimizing the efficacy of smoking cessation contests: an exploration of determinants of successful quitting. Health Educ Res 2009;24(1):54-63.

38. Wiebing MA, Bot SM, Willemsen MC. Rokers verdienen ' $n$ beloning', de 24-uur-niet-rokenactie. Blootstelling, deelname en effect op stopbereidheid bij hoge en lage welstandsgroepen. Tijdschrift voor Gezondheidswetenschappen 2010;88:435-41.

39. Gallus S, Schiaffino A, La Vecchia C, Townsend J, Fernandez E. Price and cigarette consumption in Europe. Tob Control 2006;15(2):114-9.

40. Rubery J, Grimshaw D, Figueiredo H. How to close the gender pay gap in Europe: towards the gender mainstreaming of pay policy. Industrial Relations Journal 2005;36(3):184-213.

41. Peretti-Watel P, L'Haridon O, Seror V. Responses to increasing cigarette prices in France: how did persistent smokers react? Health Policy 2012;106(2):169-76.

42. Peretti-Watel $P$, Constance J. "It's all we got left". Why poor smokers are less sensitive to cigarette price increases. Int J Environ Res Public Health 2009;6(2):608-21.

43. Licht AS, Hyland AJ, O'Connor RJ, Chaloupka FJ, Borland R, Fong GT, et al. Socio-economic variation in price minimizing behaviors: findings from the International Tobacco Control (ITC) Four Country Survey. Int J Environ Res Public Health 2011;8(1):234-52.

44. Bosdriesz JR, Willemsen MC, Stronks K, Kunst AE. Tobacco control policy development in the European Union: do political factors matter? Eur J Public Health 2015;25(2):190-4.

45. Nagelhout GE, Crone MR, van den Putte B, Willemsen MC, Fong GT, de Vries H. Age and educational inequalities in smoking cessation due to three population-level tobacco control interventions: findings from the International Tobacco Control (ITC) Netherlands Survey. Health Educ Res 2013;28(1):83-91.

46. Layte R, Whelan CT. Explaining Social Class Inequalities in Smoking: The Role of Education, SelfEfficacy, and Deprivation. Eur Sociol Rev 2009;25(4):399-410.

47. Kickbusch IS. Health literacy: addressing the health and education divide. Health Promot Int 2001;16(3):289-97.

48. Honkapohja S, Koskela E, Gerlach S, Reichlin L. The economic crisis of the 1990s in Finland. Econ Policy 1999(29):401-36.

49. Benson FE, Kuipers MA, Nierkens V, Bruggink JW, Stronks K, Kunst AE. Socioeconomic inequalities in smoking in The Netherlands before and during the Global Financial Crisis: a repeated crosssectional study. BMC Public Health 2015;15:469. 
Table 1 Countries included in the analysis, sources of data, age ranges and sample sizes

\begin{tabular}{|c|c|c|c|c|}
\hline Country & Survey year & Survey name & $\begin{array}{l}\text { Included } \\
\text { age } \\
\text { range }\end{array}$ & $\begin{array}{l}\text { Number of } \\
\text { included } \\
\text { respondents }^{\mathrm{a}}\end{array}$ \\
\hline Finland & $\begin{array}{l}\text { 1993/1995/1997/1999/2001/ } \\
2003 / 2005 / 2007\end{array}$ & Health Behaviour and Health ${ }^{b}$ & $30-79$ & $3792 \sim 4069$ \\
\hline Ireland & $1998 / 2002 / 2007$ & Survey of Lifestyle and Nutrition & $30-74$ & $4235 \sim 7638$ \\
\hline United Kingdom & $1990 / 1996 / 2000 / 2005$ & General Household Survey ${ }^{c}$ & $30-69$ & $9967 \sim 15722$ \\
\hline \multirow[t]{2}{*}{ Austria } & 1991/1999 & Micro Census & $30-79$ & $27817 \sim 28817$ \\
\hline & 2006 & Health Interview Survey & $30-79$ & 11421 \\
\hline \multirow[t]{2}{*}{ Netherlands } & 1990 & Ongoing Survey of Living Condition (DLO) & $30-79$ & 3472 \\
\hline & $1997 / 2000 / 2005$ & Permanent Survey on Living Conditions (POLS) & $30-79$ & $5665 \sim 6169$ \\
\hline France & $2000 / 2005$ & Baromètre santé & $30-74$ & $9641 \sim 20105$ \\
\hline \multirow[t]{2}{*}{ Italy } & 1990 & Multipurpose family survey & $30-79$ & 38591 \\
\hline & $2000 / 2005$ & Health and Health Care Utilization & $30-79$ & $82040 \sim 87673$ \\
\hline Portugal & $\begin{array}{l}1995-1996 / 1998-1999 / 2005- \\
2006\end{array}$ & National Health Survey & $30-79$ & $26091 \sim 30199$ \\
\hline Spain & $1993 / 2001 / 2006$ & National Health Survey & $30-79$ & $14187 \sim 23396$ \\
\hline
\end{tabular}

Notes:

a. The range of the number of respondents per year for each country.

b. The Finnish data used are combined from two Finnish studies: "Health behaviour and health among Finnish adult population (AVTK)", which includes respondents who are 15-64 years old, and "Health behaviour and health among the Finnish elderly (EVTK)", which includes respondents who are older than 64 years.

c. The General Household Survey collected information from people living in Great Britain. People from Northern Ireland were not included. 
Table 2 Summary statistics of key variables, pooled for all years in each country

\begin{tabular}{|c|c|c|c|c|c|c|c|c|c|}
\hline & Finland & Ireland & $\begin{array}{c}\text { United } \\
\text { Kingdom }\end{array}$ & Austria & Netherlands & France & Italy & Portugal & Spain \\
\hline \multicolumn{10}{|l|}{ Gender } \\
\hline men\% & $47 \%$ & $43 \%$ & $48 \%$ & $46 \%$ & $48 \%$ & $42 \%$ & $48 \%$ & $47 \%$ & $44 \%$ \\
\hline women\% & $53 \%$ & $57 \%$ & $52 \%$ & $54 \%$ & $52 \%$ & $58 \%$ & $52 \%$ & $53 \%$ & $56 \%$ \\
\hline \multicolumn{10}{|l|}{ Age } \\
\hline $30-39 \%$ & $17 \%$ & $31 \%$ & $29 \%$ & $24 \%$ & $27 \%$ & $28 \%$ & $24 \%$ & $20 \%$ & $25 \%$ \\
\hline $40-49 \%$ & $20 \%$ & $28 \%$ & $27 \%$ & $24 \%$ & $25 \%$ & $23 \%$ & $23 \%$ & $22 \%$ & $23 \%$ \\
\hline $50-59 \%$ & $19 \%$ & $19 \%$ & $24 \%$ & $21 \%$ & $21 \%$ & $23 \%$ & $21 \%$ & $21 \%$ & $19 \%$ \\
\hline $60-69 \%$ & $20 \%$ & $15 \%$ & $20 \%$ & $18 \%$ & $16 \%$ & $18 \%$ & $18 \%$ & $21 \%$ & $18 \%$ \\
\hline $70-79 \%$ & $24 \%$ & $7 \%$ & - & $13 \%$ & $11 \%$ & $8 \%$ & $14 \%$ & $16 \%$ & $15 \%$ \\
\hline \multicolumn{10}{|l|}{ Education } \\
\hline ISCED 0-2\% & $43 \%$ & $19 \%$ & $45 \%$ & $36 \%$ & $47 \%$ & $30 \%$ & $66 \%$ & $87 \%$ & $69 \%$ \\
\hline ISCED 3-4\% & $41 \%$ & $49 \%$ & $29 \%$ & $58 \%$ & $33 \%$ & $42 \%$ & $26 \%$ & $6 \%$ & $16 \%$ \\
\hline ISCED 5-6\% & $16 \%$ & $32 \%$ & $26 \%$ & $6 \%$ & $20 \%$ & $28 \%$ & $8 \%$ & $7 \%$ & $15 \%$ \\
\hline \multicolumn{10}{|l|}{ Occupation } \\
\hline manual\% & $31 \%$ & $52 \%$ & $34 \%$ & $39 \%$ & $32 \%$ & $20 \%$ & $52 \%$ & $51 \%$ & $75 \%$ \\
\hline non-manual\% & $69 \%$ & $48 \%$ & $66 \%$ & $61 \%$ & $68 \%$ & $80 \%$ & $48 \%$ & $49 \%$ & $25 \%$ \\
\hline \multicolumn{10}{|l|}{ Smoking status } \\
\hline current smoker\% & $22 \%$ & $25 \%$ & $27 \%$ & $24 \%$ & $33 \%$ & $28 \%$ & $24 \%$ & $20 \%$ & $30 \%$ \\
\hline ex/ never & $78 \%$ & $75 \%$ & $73 \%$ & $76 \%$ & $67 \%$ & $72 \%$ & $76 \%$ & $80 \%$ & $70 \%$ \\
\hline \multicolumn{10}{|l|}{ GDP } \\
\hline Mean & 27679 & 37555 & 29629 & 30454 & 33716 & 29959 & 28322 & 20068 & 25720 \\
\hline Min & 21057 & 29463 & 24886 & 26991 & 27820 & 29043 & 24566 & 18136 & 20407 \\
\hline Max & 34813 & 42114 & 34519 & 35680 & 36974 & 30398 & 29544 & 22073 & 28569 \\
\hline \multicolumn{10}{|l|}{ Cigarette price } \\
\hline Mean & 1.40 & 1.64 & 2.25 & 1.15 & 0.97 & 1.45 & 1.08 & 1.67 & 0.93 \\
\hline Min & 1.24 & 1.55 & 1.86 & 1.10 & 0.82 & 1.12 & 0.98 & 1.65 & 0.80 \\
\hline Max & 1.50 & 1.79 & 2.65 & 1.22 & 1.07 & 1.60 & 1.20 & 1.72 & 0.99 \\
\hline \multicolumn{10}{|l|}{ Non-price policy } \\
\hline Mean & 55.79 & 55.80 & 29.78 & 14.46 & 35.37 & 49.51 & 55.55 & 35.26 & 49.73 \\
\hline Min & 43.64 & 24.55 & 9.09 & 1.82 & 15.45 & 40.91 & 30.00 & 30.00 & 25.45 \\
\hline Max & 68.18 & 86.36 & 52.73 & 38.18 & 60.91 & 53.64 & 75.45 & 46.36 & 73.64 \\
\hline
\end{tabular}


Figure 1 Trends in tobacco control policies in each country

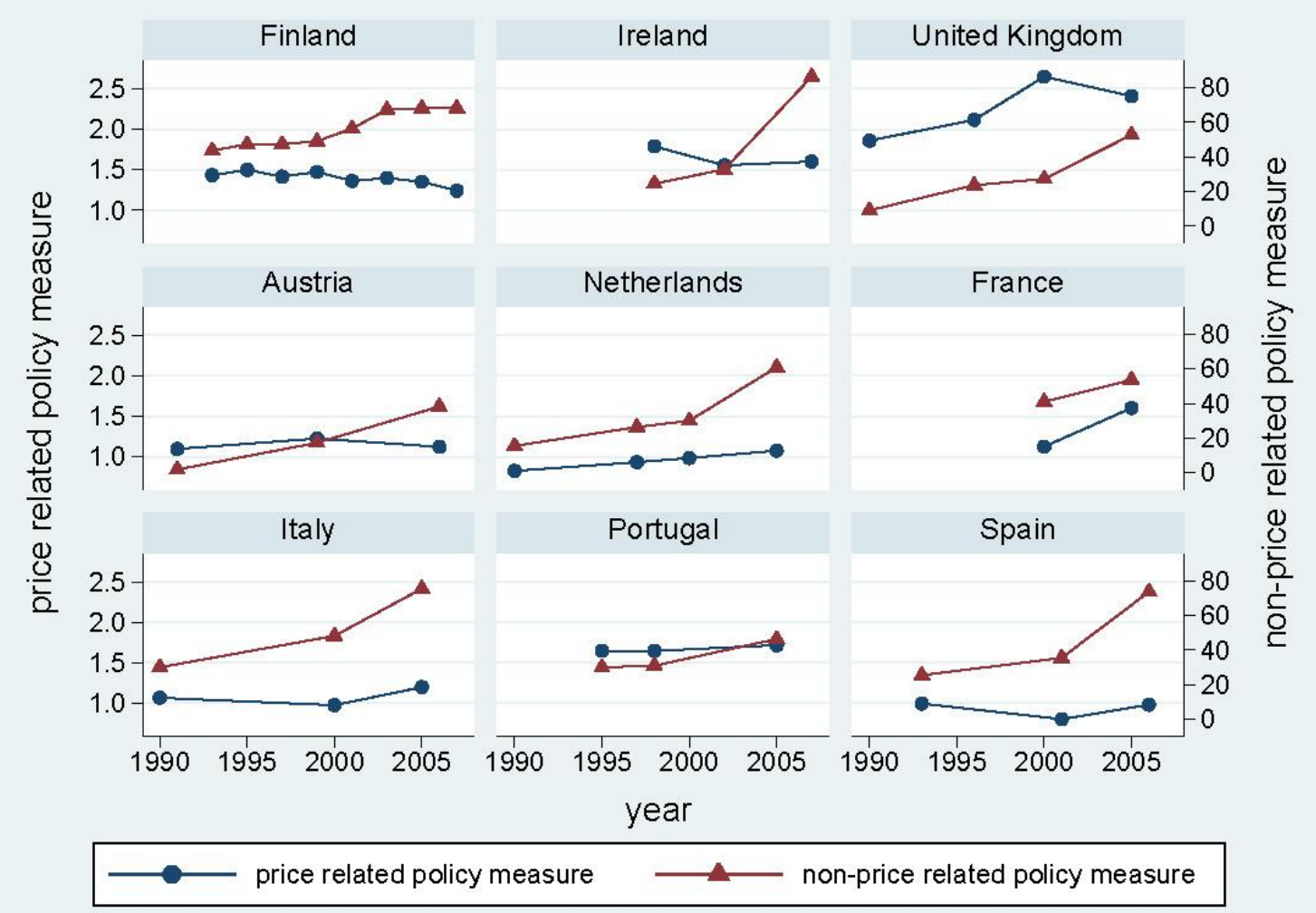


Figure 2.a Trends in age-standardized smoking prevalence by education among men in each country

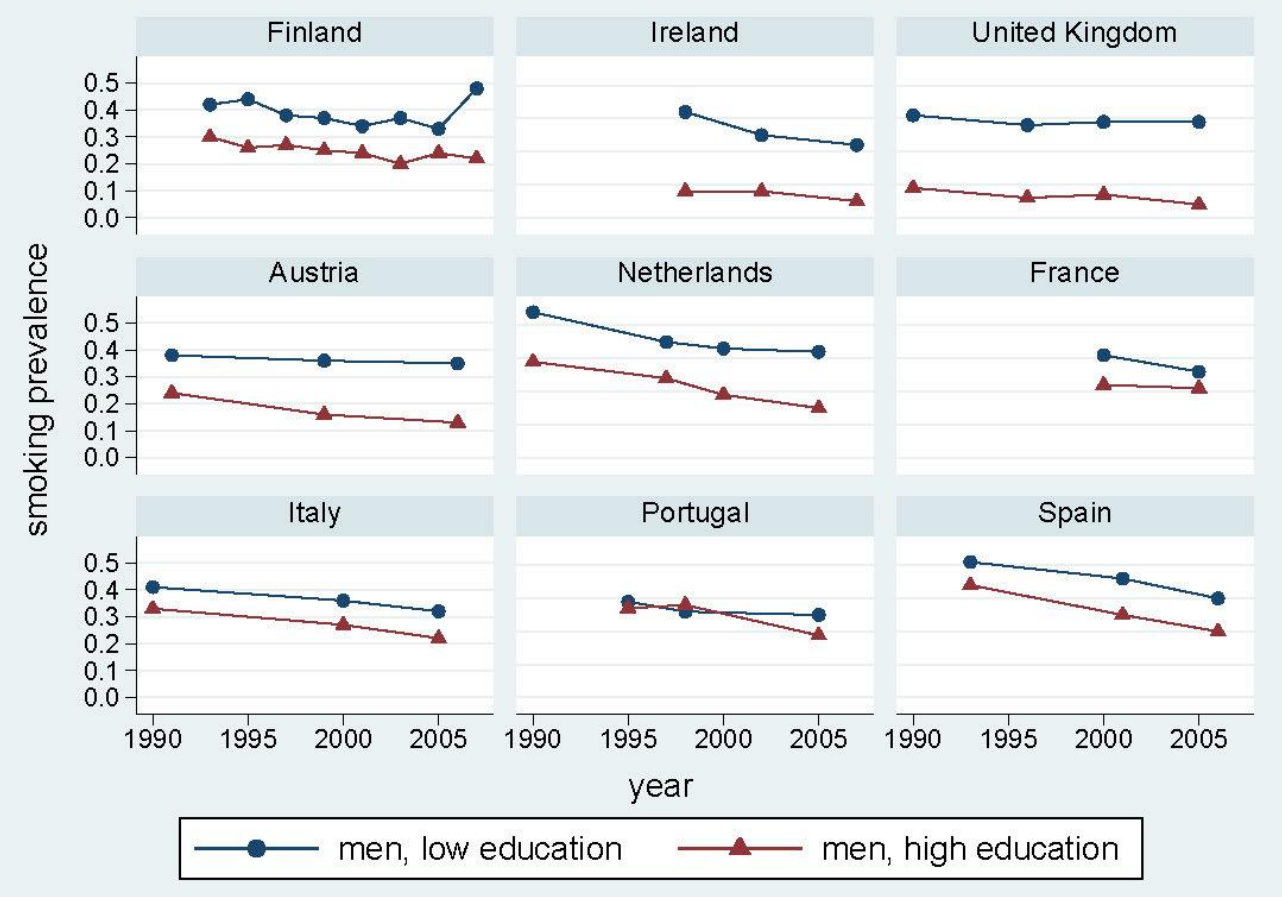

Figure 2.b Trends in age-standardized smoking prevalence by education among women in each country

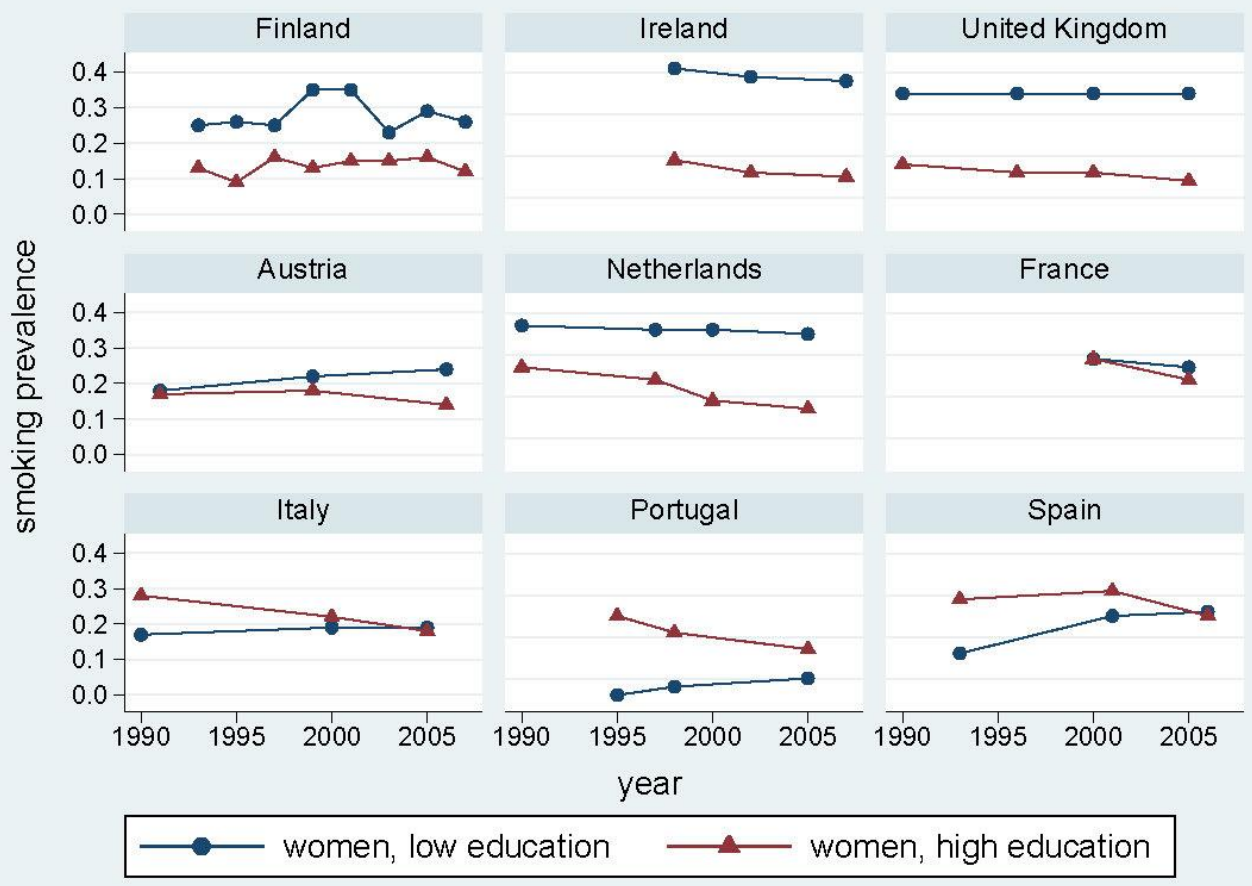


Table 3 Gender-specific associations between price and non-price related tobacco control policy measures and smoking status stratified by education and occupation

\begin{tabular}{|c|c|c|c|c|c|c|c|c|}
\hline & \multicolumn{4}{|c|}{ Men } & \multicolumn{4}{|c|}{ Women } \\
\hline & \multicolumn{2}{|r|}{ Price $^{1}$} & \multicolumn{2}{|c|}{ Non-price ${ }^{2}$} & \multicolumn{2}{|r|}{ Price $^{1}$} & \multicolumn{2}{|r|}{ Non-price ${ }^{2}$} \\
\hline & $O R^{3,4}$ & $95 \% \mathrm{Cl}$ & OR & $95 \% \mathrm{Cl}$ & OR & $95 \% \mathrm{Cl}$ & OR & $95 \% \mathrm{Cl}$ \\
\hline Total population & 0.890 & $(0.629 \sim 1.260)$ & 0.995 & $(0.991 \sim 0.999)$ & 0.502 & $(0.337 \sim 0.749)$ & 0.996 & $(0.987 \sim 1.005)$ \\
\hline Low education & 0.989 & $(0.599 \sim 1.633)$ & 0.995 & (0.992 0.999$)$ & 0.545 & $(0.365 \sim 0.815)$ & 0.994 & $(0.984 \sim 1.004)$ \\
\hline High education & 1.219 & $(0.725 \sim 2.048)$ & 0.997 & $(0.990 \sim 1.004)$ & 0.888 & $(0.545 \sim 1.446)$ & 1.000 & $(0.995 \sim 1.005)$ \\
\hline$P$ value ${ }^{5}$ & 0.260 & & 0.623 & & 0.128 & & 0.443 & \\
\hline Manual $^{6}$ & 0.852 & $(0.639 \sim 1.136)$ & 0.998 & $(0.991 \sim 1.005)$ & 0.489 & $(0.350 \sim 0.683)$ & 0.996 & $(0.988 \sim 1.004)$ \\
\hline Non-manual & 1.008 & $(0.639 \sim 1.590)$ & 0.998 & $(0.993 \sim 1.004)$ & 0.663 & $(0.426 \sim 1.032)$ & 0.994 & $(0.982 \sim 1.006)$ \\
\hline P value ${ }^{5}$ & 0.309 & & 0.600 & & 0.196 & & 0.691 & \\
\hline
\end{tabular}

${ }^{1}$ The relative income price of cigarettes (the percentage of per capita GDP required to purchase the 100 cheapest packs of cigarettes).

${ }^{2}$ Summary scores for four domains of non-price related policies (smoking bans or restrictions, comprehensive bans on advertising and promoting, health warning labels and cessation services).

${ }^{3}$ Odds ratios and $95 \%$ confidence intervals based on clustered standard errors are reported, derived from logistic regressions.

${ }^{4}$ All models were adjusted by age, age squared, logarithmic form of GDP, periods and country dummies. Significant associations and significant interactions $(p<0.05)$ are highlighted in bold.

${ }^{5} \mathrm{P}$-value for the interactions between the tobacco control policy measures and education or occupation.

${ }^{6}$ In the stratified analysis based on occupation, some recent years for Finland were excluded because information on occupation was not available. 


\section{Web appendix}

Figure A1.a Trends in age-standardized smoking prevalence by occupation among men in each country

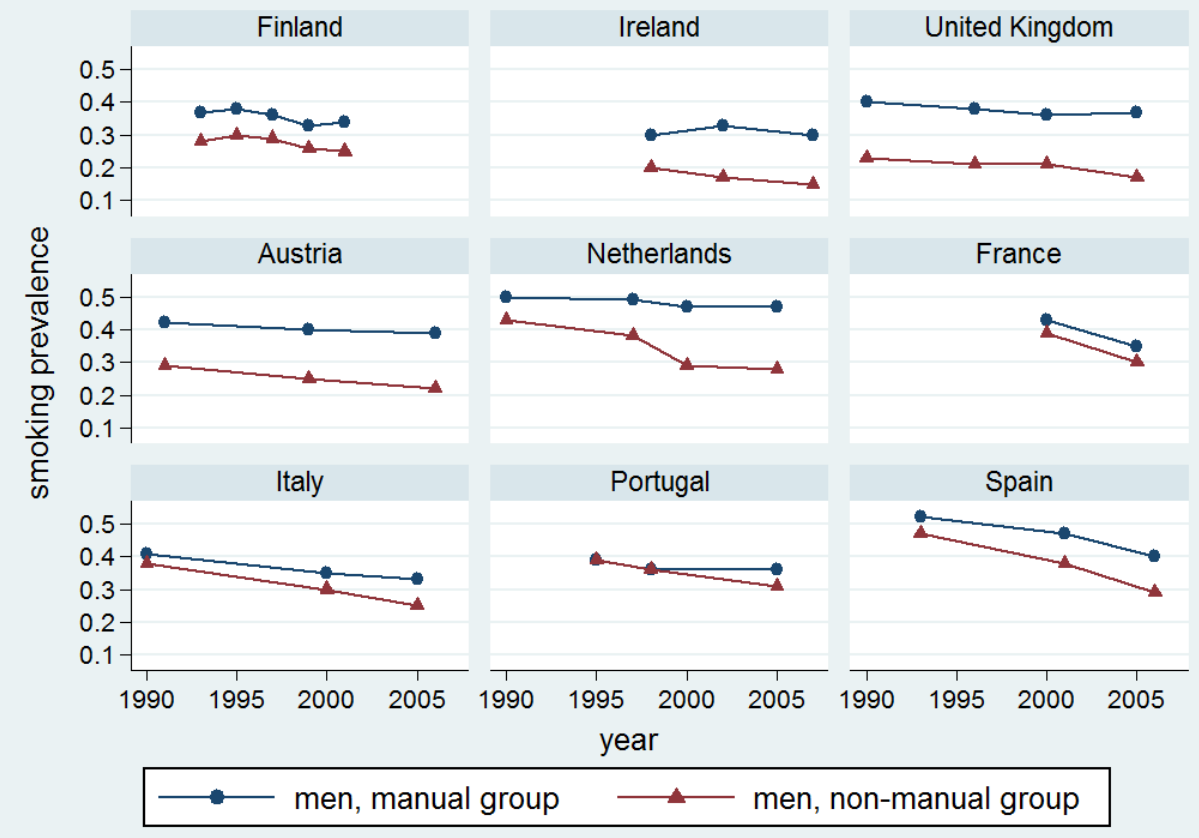

Figure A1.b Trends in age-standardized smoking prevalence by occupation among women in each country

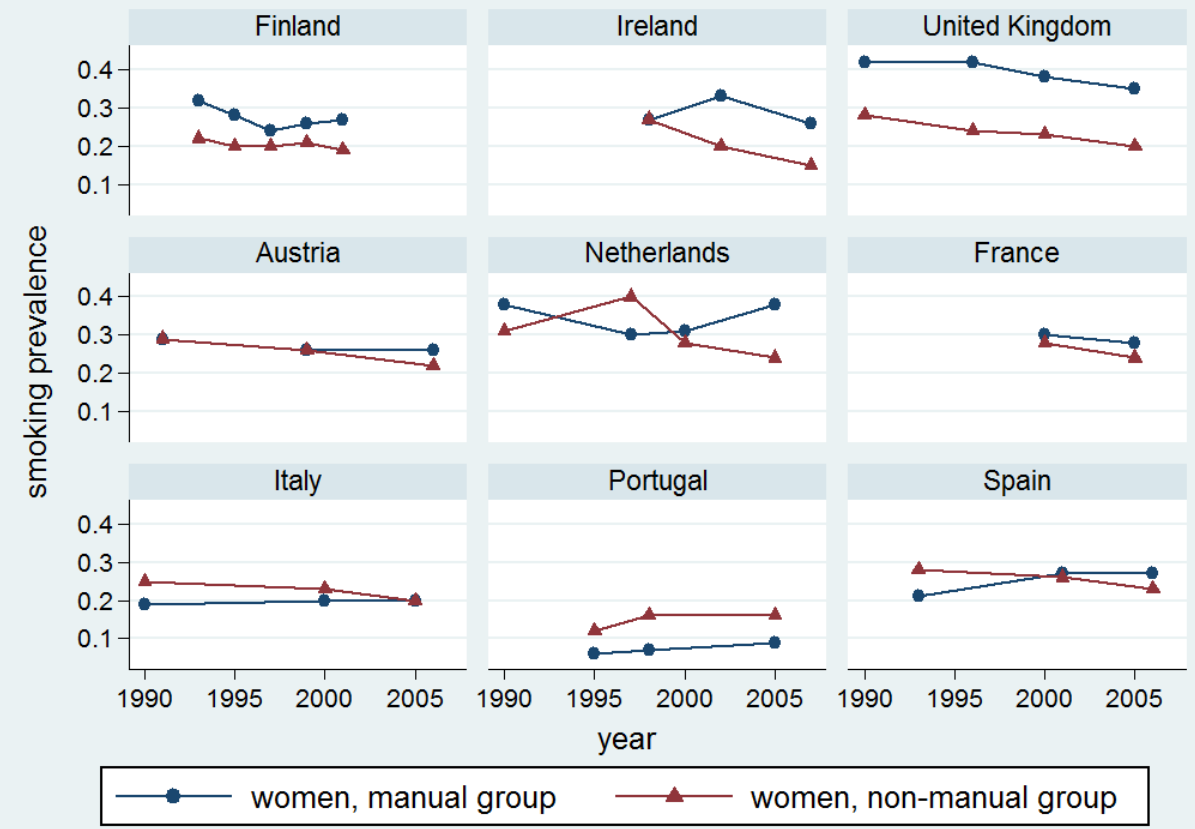


Table A1 Gender-specific associations between price and non-price related tobacco control policy measures and smoking status stratified by education and occupation, weighted results

\begin{tabular}{|c|c|c|c|c|c|c|c|c|}
\hline & \multicolumn{4}{|c|}{ Men } & \multicolumn{4}{|c|}{ Women } \\
\hline & \multicolumn{2}{|r|}{ Price $^{1}$} & \multicolumn{2}{|c|}{ Non-price ${ }^{2}$} & \multicolumn{2}{|r|}{ Price $^{1}$} & \multicolumn{2}{|c|}{ Non-price ${ }^{2}$} \\
\hline & $\mathrm{OR}^{3,4}$ & $95 \% \mathrm{Cl}$ & OR & $95 \% \mathrm{Cl}$ & OR & $95 \% \mathrm{Cl}$ & OR & $95 \% \mathrm{Cl}$ \\
\hline Total population & 0.975 & $(0.703 \sim 1.352)$ & 0.993 & $(0.990 \sim 0.996)$ & 0.539 & $(0.344 \sim 0.845)$ & 0.993 & $(0.983 \sim 1.004)$ \\
\hline Low education & 1.003 & $(0.606 \sim 1.659)$ & 0.995 & (0.991 0.998) & 0.525 & $(0.365 \sim 0.754)$ & 0.994 & $(0.983 \sim 1.004)$ \\
\hline High education & 1.313 & $(0.847 \sim 2.036)$ & 0.996 & $(0.990 \sim 1.002)$ & 0.976 & $(0.595 \sim 1.603)$ & 0.996 & $(0.991 \sim 1.001)$ \\
\hline$P$ value ${ }^{5}$ & 0.056 & & 0.696 & & 0.035 & & 0.706 & \\
\hline Manual $^{6}$ & 0.911 & $(0.732 \sim 1.133)$ & 0.996 & $(0.990 \sim 1.001)$ & 0.575 & $(0.395 \sim 0.838)$ & 0.992 & $(0.984 \sim 1.001)$ \\
\hline Non-manual & 1.180 & $(0.799 \sim 1.743)$ & 0.996 & $(0.990 \sim 1.003)$ & 0.673 & $(0.430 \sim 1.052)$ & 0.992 & $(0.979 \sim 1.005)$ \\
\hline$P$ value ${ }^{5}$ & 0.122 & & 0.786 & & 0.520 & & 0.926 & \\
\hline
\end{tabular}

${ }^{1}$ The relative income price of cigarettes (the percentage of per capita GDP required to purchase the 100 cheapest packs of cigarettes).

${ }^{2}$ Summary scores for four domains of non-price related policies (smoking bans or restrictions, comprehensive bans on advertising and promoting, health warning labels and cessation services).

${ }^{3}$ Odds ratios and $95 \%$ confidence intervals based on clustered standard errors are reported, derived from logistic regressions.

${ }^{4}$ All models were adjusted by age, age squared, logarithmic form of GDP, periods and country dummies. Significant associations and significant interactions $(p<0.05)$ are highlighted in bold.

${ }^{5} \mathrm{P}$-value for the interactions between the tobacco control policy measures and education or occupation.

${ }^{6}$ In the stratified analysis based on occupation, some recent years for Finland were excluded because information on occupation was not available. 
Table A2 Gender-specific associations between price and non-price related tobacco control policy measures and amount of smoking ${ }^{1}$ stratified by education and occupation

\begin{tabular}{|c|c|c|c|c|c|c|c|c|}
\hline & \multicolumn{4}{|c|}{ Men } & \multicolumn{4}{|c|}{ Women } \\
\hline & \multicolumn{2}{|r|}{ Price $^{2}$} & \multicolumn{2}{|r|}{ Non-price ${ }^{3}$} & \multicolumn{2}{|r|}{ Price $^{2}$} & \multicolumn{2}{|r|}{ Non-price ${ }^{3}$} \\
\hline & Coeff ${ }^{4,5}$ & $95 \% \mathrm{Cl}$ & Coeff & $95 \% \mathrm{Cl}$ & Coeff & $95 \% \mathrm{Cl}$ & Coeff & $95 \% \mathrm{Cl}$ \\
\hline Total population & -0.340 & $(-0.725 \sim 0.045)$ & -0.009 & $(-0.024 \sim 0.006)$ & -0.296 & $(-0.640 \sim 0.048)$ & -0.010 & $(-0.027 \sim 0.007)$ \\
\hline Low education & -0.258 & $(-0.659 \sim 0.142)$ & -0.014 & $(-0.029 \sim 0.001)$ & -0.273 & $(-0.629 \sim 0.082)$ & -0.015 & $(-0.035 \sim 0.006)$ \\
\hline High education & -0.364 & $(-0.829 \sim 0.101)$ & -0.010 & $(-0.020 \sim 0.001)$ & -0.304 & $(-0.708 \sim 0.100)$ & -0.014 & $(-0.026 \sim-0.002)$ \\
\hline P value 6 & 0.355 & & 0.163 & & 0.688 & & 0.865 & \\
\hline Manual $^{7}$ & -0.365 & $(-0.748 \sim 0.019)$ & -0.016 & $(-0.028 \sim-0.004)$ & -0.347 & $(-0.642 \sim-0.052)$ & -0.025 & $(-0.037 \sim-0.013)$ \\
\hline Non-manual & -0.480 & $(-1.092 \sim 0.132)$ & -0.011 & $(-0.025 \sim 0.004)$ & -0.210 & $(-0.599 \sim 0.179)$ & -0.004 & $(-0.022 \sim 0.013)$ \\
\hline P value ${ }^{6}$ & 0.320 & & 0.084 & & 0.202 & & 0.013 & \\
\hline
\end{tabular}

${ }^{1}$ The number of cigarettes were log-transformed.

2 The relative income price of cigarettes (the percentage of per capita GDP required to purchase the 100 cheapest packs of cigarettes).

${ }^{3}$ Summary scores for four domains of non-price related policies (smoking bans or restrictions, comprehensive bans on advertising and promoting, health warning labels and cessation services).

${ }^{4}$ Coefficients and $95 \%$ confidence intervals based on clustered standard errors are reported, derived from linear regressions.

${ }^{5}$ All models were adjusted by age, age squared, logarithmic form of GDP, periods and country dummies. Significant associations and significant interactions $(p<0.05)$ are highlighted in bold.

${ }^{6} \mathrm{P}$-value for the interactions between the tobacco control policy measures and education or occupation.

${ }^{7}$ In the stratified analysis based on occupation, some recent years for Finland were excluded because information on occupation was not available. 
Table A3 Gender-specific associations between the tobacco control policy measures and smoking status stratified by education and occupation adding the lagged terms of non-price policy indicator

\begin{tabular}{|c|c|c|c|c|c|c|}
\hline \multicolumn{7}{|c|}{ Men } \\
\hline & \multicolumn{2}{|r|}{ Non-price $^{1}$} & \multicolumn{2}{|c|}{ Non-price_1d ${ }^{1}$} & \multicolumn{2}{|c|}{ Non-price_2 $\mathrm{d}^{1}$} \\
\hline & $\mathrm{OR}^{2,3}$ & $95 \% \mathrm{Cl}$ & OR & $95 \% \mathrm{Cl}$ & OR & $95 \% \mathrm{Cl}$ \\
\hline Total population & 0.992 & $(0.989 \sim 0.996)$ & 1.004 & $(0.999 \sim 1.009)$ & 1.000 & $(0.993 \sim 1.008)$ \\
\hline Low education & 0.994 & $(0.990 \sim 0.999)$ & 0.999 & $(0.992 \sim 1.005)$ & 1.005 & $(0.994 \sim 1.017)$ \\
\hline High education & 0.995 & $(0.988 \sim 1.002)$ & 1.002 & $(0.998 \sim 1.005)$ & 1.003 & $(0.997 \sim 1.009)$ \\
\hline$P$ value 4 & 0.874 & & 0.474 & & 0.692 & \\
\hline Manual $^{5}$ & 0.994 & $(0.988 \sim 1.000)$ & 1.004 & $(0.994 \sim 1.014)$ & 1.003 & $(0.990 \sim 1.016)$ \\
\hline Non-manual & 0.996 & $(0.989 \sim 1.002)$ & 1.004 & $(0.993 \sim 1.016)$ & 1.000 & $(0.989 \sim 1.012)$ \\
\hline \multirow[t]{4}{*}{$P_{\text {value }}^{4}$} & 0.212 & & 0.843 & & 0.573 & \\
\hline & \multicolumn{4}{|c|}{ Women } & & \\
\hline & \multicolumn{2}{|r|}{ Non-price $^{1}$} & \multicolumn{2}{|c|}{ Non-price_1 $1 d^{1}$} & \multicolumn{2}{|c|}{ Non-price_2d ${ }^{1}$} \\
\hline & $O R^{2,3}$ & $95 \% \mathrm{Cl}$ & OR & $95 \% \mathrm{Cl}$ & OR & $95 \% \mathrm{Cl}$ \\
\hline Total population & 1.001 & $(0.994 \sim 1.008)$ & 0.994 & $(0.982 \sim 1.005)$ & 0.997 & $(0.984 \sim 1.011)$ \\
\hline Low education & 0.997 & $(0.990 \sim 1.005)$ & 0.997 & $(0.990 \sim 1.004)$ & 0.990 & $(0.980 \sim 1.001)$ \\
\hline High education & 0.997 & $(0.991 \sim 1.002)$ & 1.009 & $(0.999 \sim 1.019)$ & 0.995 & $(0.984 \sim 1.005)$ \\
\hline P value $^{4}$ & 0.941 & & 0.149 & & 0.667 & \\
\hline Manual $^{5}$ & 1.000 & $(0.991 \sim 1.009)$ & 0.995 & $(0.984 \sim 1.006)$ & 1.000 & $(0.996 \sim 1.020)$ \\
\hline Non-manual & 0.997 & $(0.988 \sim 1.006)$ & 1.008 & $(0.996 \sim 1.020)$ & 0.983 & $(0.972 \sim 0.995)$ \\
\hline$P$ value ${ }^{4}$ & 0.537 & & 0.182 & & 0.075 & \\
\hline
\end{tabular}

\footnotetext{
${ }_{1}^{1}$ Non-price_1d represents the 1-year lagged term of the non-price related policy measure. Non-price_2d represents the 2-year lagged term of the non-price related policy measure.

${ }^{2}$ Odds ratios and $95 \%$ confidence intervals based on clustered standard errors are reported, derived from logistic regressions.

${ }^{3}$ All models were adjusted by relative income price of cigarettes, age, age squared, logarithmic form of GDP, periods and country dummies. Significant associations and significant interactions $(p<0.05)$ are highlighted in bold. ${ }^{4} \mathrm{P}$-value for the interactions between the tobacco control policy measures and education or occupation.

${ }^{5}$ In the stratified analysis based on occupation, some recent years for Finland were excluded because information on occupation was not available.
} 
Table A4 Gender-specific associations between price (another set of price measure) and non-price related tobacco control policy measures and smoking status stratified by education and occupation

\begin{tabular}{|c|c|c|c|c|c|c|c|c|}
\hline & \multicolumn{4}{|c|}{ Men } & \multicolumn{4}{|c|}{ Women } \\
\hline & \multicolumn{2}{|r|}{ Price $^{1}$} & \multicolumn{2}{|c|}{ Non-price ${ }^{2}$} & \multicolumn{2}{|r|}{ Price $^{1}$} & \multicolumn{2}{|r|}{ Non-price ${ }^{2}$} \\
\hline & $\mathrm{OR}^{3,4}$ & $95 \% \mathrm{Cl}$ & OR & $95 \% \mathrm{Cl}$ & OR & $95 \% \mathrm{Cl}$ & OR & $95 \% \mathrm{Cl}$ \\
\hline Total population & 0.859 & $(0.744 \sim 0.991)$ & 0.996 & (0.992 0.999) & 1.044 & $(0.670 \sim 1.625)$ & 0.996 & $(0.988 \sim 1.004)$ \\
\hline Low education & 0.852 & $(0.703 \sim 1.034)$ & 0.996 & (0.993 0.999) & 1.089 & $(0.760 \sim 1.560)$ & 0.993 & $(0.983 \sim 1.003)$ \\
\hline High education & 1.151 & $(0.809 \sim 1.638)$ & 0.997 & $(0.990 \sim 1.003)$ & 0.771 & $(0.539 \sim 1.103)$ & 1.000 & $(0.996 \sim 1.005)$ \\
\hline Pvalue $^{5}$ & 0.145 & & 0.915 & & 0.258 & & 0.272 & \\
\hline Manual $^{6}$ & 0.796 & $(0.673 \sim 0.943)$ & 0.998 & $(0.991 \sim 1.006)$ & 0.870 & $(0.591 \sim 1.281)$ & 0.997 & $(0.989 \sim 1.005)$ \\
\hline Non-manual & 0.839 & $(0.661 \sim 1.064)$ & 0.999 & $(0.994 \sim 1.004)$ & 0.900 & $(0.691 \sim 1.172)$ & 0.995 & $(0.981 \sim 1.010)$ \\
\hline Pvalue $^{5}$ & 0.651 & & 0.524 & & 0.890 & & 0.817 & \\
\hline
\end{tabular}

${ }^{1}$ The cigarette price scores developed by Bosdriesz [refs], which measure the price of a pack of cigarettes in the most popular price category divided by GDP per capita expressed in purchasing power standards.

${ }^{2}$ Summary scores for four domains of non-price related policies (smoking bans or restrictions, comprehensive bans on advertising and promoting, health warning labels and cessation services).

${ }^{3}$ Odds ratios and $95 \%$ confidence intervals based on clustered standard errors are reported, derived from logistic regressions.

${ }^{4}$ All models were adjusted by age, age squared, logarithmic form of GDP, periods and country dummies. Significant associations and significant interactions $(p<0.05)$ are highlighted in bold.

${ }^{5} \mathrm{P}$-value for the interactions between the tobacco control policy measures and education or occupation.

${ }^{6}$ In the stratified analysis based on occupation, some recent years for Finland were excluded because information on occupation was not available. 
Table A5 Gender-specific associations between a constructed measure combining the price and nonprice related policy measures and smoking status stratified by education and occupation

\begin{tabular}{|c|c|c|c|c|}
\hline & & Men & & Jomen \\
\hline & price and & -price combined ${ }^{1}$ & price an & 1-price combined ${ }^{1}$ \\
\hline & $\mathrm{OR}^{2,3}$ & $95 \% \mathrm{Cl}$ & OR & $95 \% \mathrm{Cl}$ \\
\hline Total population & 0.992 & (0.984 0.9995) & 0.986 & $(0.972 \sim 1.000)$ \\
\hline Low education & 0.995 & $(0.985 \sim 1.004)$ & 0.983 & $(0.970 \sim 0.997)$ \\
\hline High education & 0.999 & $(0.984 \sim 1.014)$ & 1.000 & $(0.991 \sim 1.010)$ \\
\hline P value $^{4}$ & 0.404 & & 0.132 & \\
\hline Manual $^{5}$ & 0.996 & $(0.987 \sim 1.005)$ & 0.985 & $(0.976 \sim 0.995)$ \\
\hline Non-manual & 1.000 & $(0.989 \sim 1.011)$ & 0.987 & $(0.969 \sim 1.004)$ \\
\hline$P$ value ${ }^{4}$ & 0.350 & & 0.845 & \\
\hline
\end{tabular}

${ }^{1}$ Following the same weights used for TCS, we allocated 30 points to the highest price measure (the United Kingdom in 2000) and scaled the price measure in other years and countries correspondingly. We also rebased the non-price related policy measure to a maximum score of 55. The price and non-price combined was the sum of the rebased price measure and the rebased non-price measure.

${ }^{2}$ Odds ratios and $95 \%$ confidence intervals based on clustered standard errors are reported, derived from logistic regressions.

${ }^{3}$ All models were adjusted by age, age squared, logarithmic form of GDP, periods and country dummies. Significant associations and significant interactions $(p<0.05)$ are highlighted in bold.

${ }^{4} \mathrm{P}$-value for the interactions between the tobacco control policy measures and education or occupation.

${ }^{5}$ In the stratified analysis based on occupation, some recent years for Finland were excluded because information on occupation was not available. 
Table A6 Gender-specific associations between each of the four domains of the non-price policy score and smoking status stratified by education and occupation

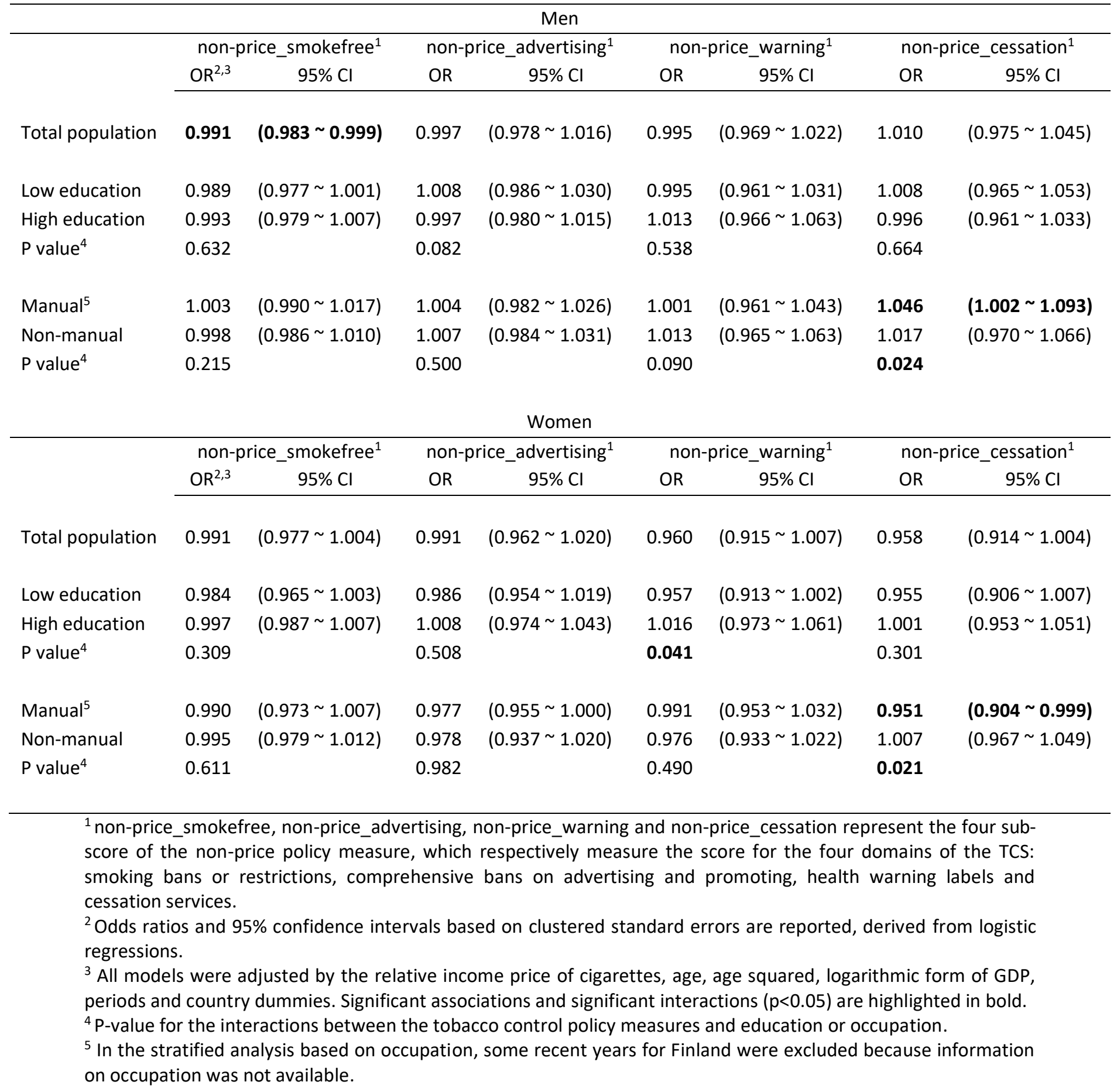

